\title{
Impact of Physico-Chemical Parameters on Finfish Eggs Diversity from Muthupettai, South East Coast of India
}

\author{
Selvam J*, Varadharajan D, Babu D and Balasubramanian T
}

Faculty of Marine Sciences, Centre of Advanced Study in Marine Biology, Annamalai University, Parangipettai-608 502, Tamil Nadu, India

\begin{abstract}
Physical and chemical parameters can determine the species diversity and abundance in particular area. Environmental parameters such as rainfall, atmospheric temperature, water temperature, salinity, $\mathrm{pH}$ and dissolved oxygen were recorded and correlated with the distribution of fish eggs. It is evident from the present study that the water temperature and salinity appear to play a significant role in determining the distribution of fin fish eggs in the study area. The time and intensity of spawning of fishes may perhaps be controlled by the seasonal cycle of the environmental factors. The physico-chemical parameters recorded from various stations presently showed monthly seasonal and annual variations.
\end{abstract}

Keywords: Fin fish eggs; Physico-chemical; Disturbance; Dispersion; Species survive

\section{Introduction}

Predation, food availability $[1,2]$ and environmental parameters have been pointed out as the main factors influencing ichthyoplankton dynamics. Among environmental parameters, temperature, salinity and river flow [3] are considered the most important variables affecting icthyoplankton communities in estuarine systems. Community level studies supply information on several aspects of species biology, allowing for the determination of spatial and temporal evolution of ichthyoplankton distribution [4], thus establishing preferred spawning grounds and seasons [5]. Moreover, it is also possible to identify factors that influence recruitment variability [6,7]. Estuaries are unstable systems, generally having a limited number of species present. However, they may support high abundance of organisms due to their high productivity, providing important nursery areas where ichthyoplankton encounter suitable conditions for enhanced development [8]. Mangroves posses in varying degrees marine, brackish and fresh water fish components. Their distribution depends upon the geographical biological, ecological and physiochemical characteristics of the water. It is well known that the mangroves are used as nursery and breeding history of fishes. The hydrodynamic conditions in an estuary are quite complex, as they are influenced by river flow, tide, wind and density factors. Further, they are modified due to earth's rotation, bottom friction and the geometric properties of the estuarine system [9]. Physico-chemical and biological, ecological condition are generally subjects to the eggs and larvae to high rate of mortality in the environment. Hydrological study is a prerequisite to the assessment of the potentialities, distribution of plants and animals and also to understand the realities between its different trophic level and food webs. In Indian estuaries and seas the physicochemical characteristics have been studied by many workers [10-14] in west coast. Major estuarine systems in India are situated on the east coast. Several studies on hydrography of estuarine and coastal waters were carried out from east coast of India [15-18]. Qasim [19] stated that the tropical estuaries are influenced mainly by the monsoonal rain which brings profound changes in the hydrography. The physico-chemical parameters observed in the present study were found to be influenced mostly by the monsoonal rainfall that determines seasons.

\section{Materials and Methods}

Monthly water samples were collected from Muthupettai at four different stations. Rainfall data were obtained from the Indian Meteorological Department Division functioning at Nagapattinam collectorate office, for a period of two years from January-2010 to December-2011. Temperature $\left({ }^{\circ} \mathrm{C}\right)$ was measured using a standard Celsius thermometer with the accuracy of $\pm 0.5{ }^{\circ} \mathrm{C}$. Salinity was measured with the help of an E-2 model Refractometer. The $\mathrm{pH}$ was measured with the aid of an Elico model LI $120 \mathrm{pH}$ meter. Dissolved oxygen, and Biochemical Oxygen Demand (BOD) were analysed immediately after collection in the laboratory, following Winkler's method as described by Strickland and Parsons [20].

\section{Results}

\section{Rainfall}

The total annual rainfall of $1271.4 \mathrm{~mm}$ was recorded during (2010). Maximum rainfall $302(\mathrm{~mm})$ was in October-2010 and the minimum $10(\mathrm{~mm})$ in January 2010 . The total annual rainfall recorded during (2011), was $1225.3 \mathrm{~mm}$. The maximum rainfall $(289 \mathrm{~mm})$ was recorded in October-2011 and the minimum $(30.2 \mathrm{~mm})$ was in February-2011 (Figure 1).

\section{Atmospheric temperature}

During 2010 at station I, the surface water temperature varied between $35^{\circ} \mathrm{C}$ (April) and 25 (October). At station II, the temperature fluctuated between $34.5^{\circ} \mathrm{C}$ (May) and $24.3^{\circ} \mathrm{C}$ (December). At station III, the Atmospheric temperature ranged from $35^{\circ} \mathrm{C}$ (May) to $26^{\circ} \mathrm{C}$ (October). At station IV, the temperature varied from $25.3^{\circ} \mathrm{C}$ (November) to $34.2^{\circ} \mathrm{C}$ (Jun), (Figure 2).

During 2011 at station I, the temperature varied between $24^{\circ} \mathrm{C}$

*Corresponding author: J. Selvam, Faculty of Marine Sciences, Centre of Advanced Study in Marine Biology, Annamalai University, Parangipettai-608502, Tamil Nadu, India, Tel: 04144-243223; Fax: 04144243553; E-mail: jagaselvam@yahoo.com

Received August 06, 2013; Accepted August 11, 2013; Published August 14 2013

Citation: Selvam J, Varadharajan D, Babu D, Balasubramanian T (2013) Impact of Physico-Chemical Parameters on Finfish Eggs Diversity from Muthupettai, South East Coast of India. J Environ Anal Toxicol 3: 185. doi:10.4172/2161-0525.1000185

Copyright: ( 2013 Selvam J, et al. This is an open-access article distributed under the terms of the Creative Commons Attribution License, which permits unrestricted use, distribution, and reproduction in any medium, provided the original author and source are credited. 
Citation: Selvam J, Varadharajan D, Babu D, Balasubramanian T (2013) Impact of Physico-Chemical Parameters on Finfish Eggs Diversity from Muthupettai, South East Coast of India. J Environ Anal Toxicol 3: 185. doi:10.4172/2161-0525.1000185

Page 2 of 5

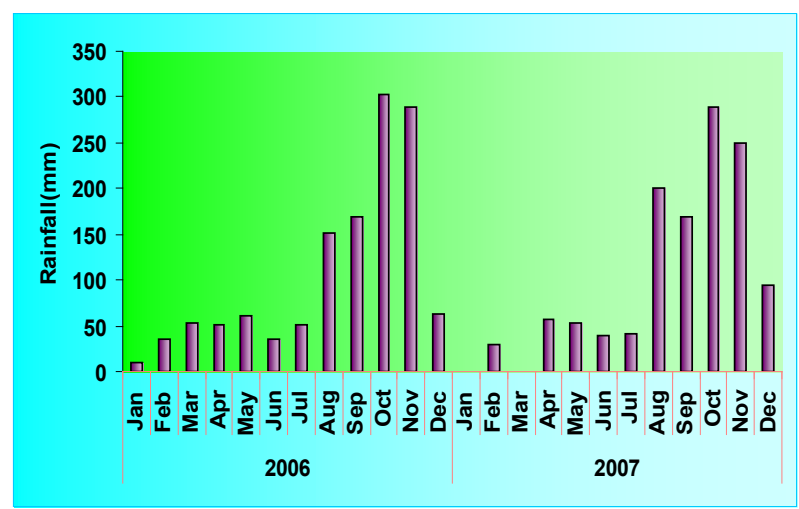

Figure 1: Rainfall recorded along Muthupettai coast (2010 -2011).

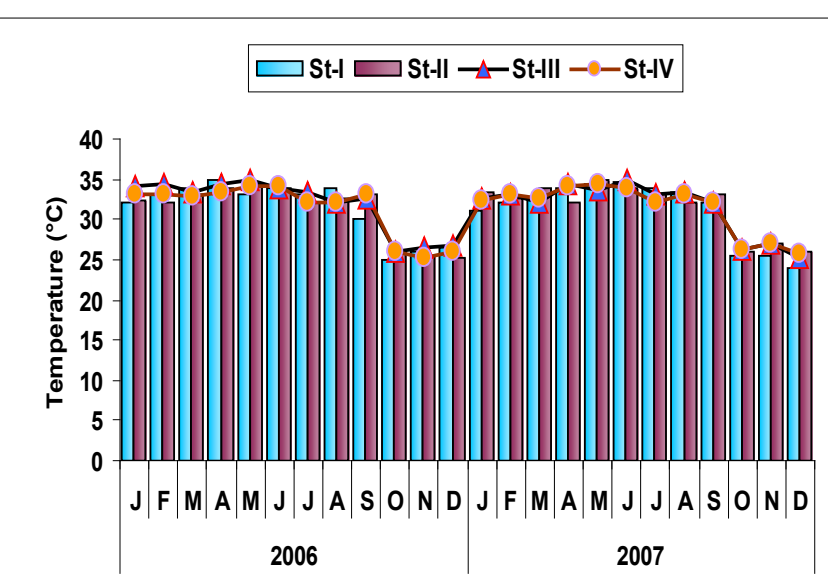

Figure 2: Atmospheric temperature recorded along Muthupettai (January-2010 to December-2011).

(December) and $34.6^{\circ} \mathrm{C}$ (May). At station II, the temperature fluctuated from $24.9^{\circ} \mathrm{C}$ (December) to $34.8^{\circ} \mathrm{C}$ (May). At station III, it varied from 25.3 (December) to 35 (June). With respect to station IV, it fluctuated between $25.8^{\circ} \mathrm{C}$ (December) and $34.3^{\circ} \mathrm{C}$ (May).

\section{Water temperature}

During the year 2010 , the water temperature varied between $18.6^{\circ} \mathrm{C}$ (December) and $29.4^{\circ} \mathrm{C}$ (January). In station II, the temperature fluctuated from $18.5^{\circ} \mathrm{C}$ (October) to $29^{\circ} \mathrm{C}$ (July, September). In station III, it varied from $19^{\circ} \mathrm{C}$ (October) to $28^{\circ} \mathrm{C}$ (April, July). At station IV, it ranged between $16.9^{\circ} \mathrm{C}$ (December) and $28^{\circ} \mathrm{C}$ (January).

During 2011, the surface water temperature varied from $16.5^{\circ} \mathrm{C}$ (December) to $30.1^{\circ} \mathrm{C}$ (May). At station II, water temperature varied from $18.6^{\circ} \mathrm{C}$ (October) to $29^{\circ} \mathrm{C}$ (September), from $16.5^{\circ} \mathrm{C}$ (December) to $28^{\circ} \mathrm{C}$ (February, September) to station III. At station IV, the temperature varied from $17^{\circ} \mathrm{C}$ (December) to $27.4^{\circ} \mathrm{C}$ (April). In general, the water temperature level increased from monsoon season, reaching the maximum during the summer months (Figure 3 ).

Two-way analysis of variance done for the two years of study period showed significant differences between the seasons (Table 1).

The Analysis of Variance (ANOVA) of water temperature between seasons and between stations showed significant at $0.05 \%$ level.

\section{Salinity}

During (2010), the salinity varied between 20\%o (December) and
$33 \%$ (July) at station I, from $18 \%$ o (November) to 33\%o (May and June) at station II, at station III, the minimum salinity was recorded in October $(18 \%$ ) and maximum in May (33\%o). At station IV, the salinity fluctuated between $16 \%$ (November) and 35\% (May). During (2011), the salinity varied between $17 \%$ (November and December) and 33\% in August, May and July at station I. 15\%o (November) and $33 \%$ (May) in station II. 16\%o (October) and $34 \%$ (May) in station III. In station IV, it ranged between $16 \%$ (November) and -36\%o (May). The fluctuations in salinity may be attributed due to rainfall and monsoonal flood. However, the minimum salinity was recorded during monsoon and the maximum in summer (Figure 4).

Two-way analysis of variance done separately for the two years of study period showed in Table 2 .

The results of Analysis of Variance (ANOVA) of salinity are presented in table 2. Variations in salinity between stations and between seasons were significant at $0.05 \%$ level.

\section{pH}

The $\mathrm{pH}$ values ranged between 7.9 (April) and 8.3 (June) at station I, 7.2 (December) and 8.2 (May) in station II, between 7.3 (December) and 8.2 (May) at station III, 7.2 (December) and 8.2 (May) in station IV during the year 2010 (Figure 5).

During 2011, the pH ranged from 7.5 (November) to 8.2 (Jun) in station I, from7.7 (November) to 8.2 (May) in station II, from 7.6

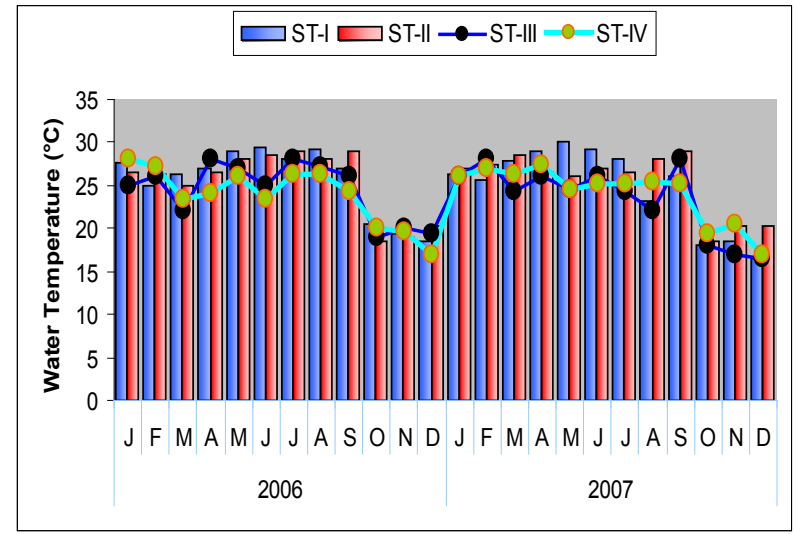

Figure 3: Surface water temperature recorded during along Muthupettai waters (2010-2011).

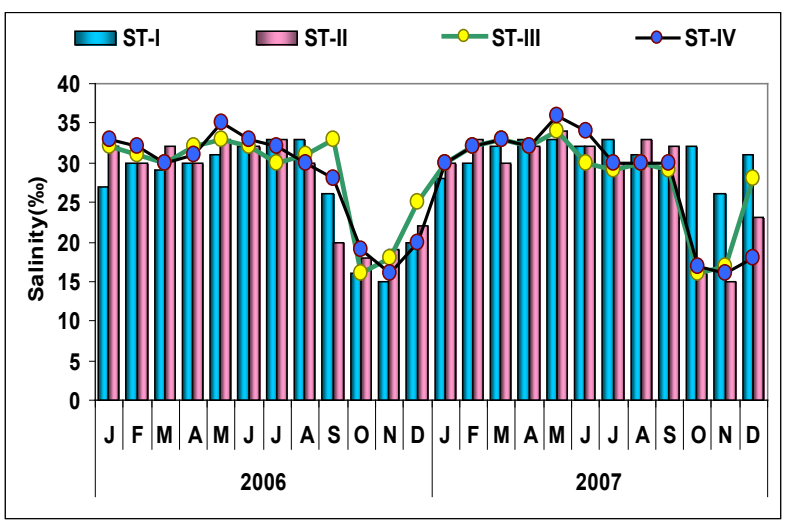

Figure 4: Salinity variation at Muthupettai (January-2010 to December-2011) 
Citation: Selvam J, Varadharajan D, Babu D, Balasubramanian T (2013) Impact of Physico-Chemical Parameters on Finfish Eggs Diversity from Muthupettai, South East Coast of India. J Environ Anal Toxicol 3: 185. doi:10.4172/2161-0525.1000185

(November) to 8.3 (Jun) in station III and between 7.8 (December) and 8.2 (Jun) in station IV.

The Analysis of Variance (ANOVA) of $\mathrm{pH}$ between seasons and between stations showed significant at $0.05 \%$ level (Table 3 ).

\section{Dissolved oxygen}

The dissolved oxygen values recorded during the study period (January-2010 to June - 2011) are shown in Figure 6. During (2010), the dissolved oxygen values varied from $5.66 \mathrm{mg} / \mathrm{l}$ (February) to 4.11 $\mathrm{mg} / \mathrm{l}$ (July) in station I, from $5.0 \mathrm{mg} / \mathrm{l}$ (February) to $2.8 \mathrm{mg} / \mathrm{l}$ (October) at station II, at station III, between $4.5 \mathrm{mg} / \mathrm{l}$ (June) and $3.1 \mathrm{mg} / \mathrm{l}$ (September). In station IV, the maximum dissolved oxygen value was recorded $(5.54 \mathrm{mg} / \mathrm{l})$ during February and the minimum $(4.0 \mathrm{mg} / \mathrm{l})$ in November-2010.

During the year 2011, at station I, dissolved oxygen varied between $4.5 \mathrm{mg} / \mathrm{l}$ (July) and $3.5 \mathrm{mg} / \mathrm{l}$ (December). At station II, dissolved oxygen ranged between $4.5 \mathrm{mg} / \mathrm{l}$ (July) and $2.9 \mathrm{mg} / \mathrm{l}$ (March). At station III, the dissolved oxygen varied from $4.7 \mathrm{mg} / \mathrm{l}$ (July) to $3.1 \mathrm{mg} / \mathrm{l}$ (December) and at station IV, it varied ranged from $4.2 \mathrm{mg} / \mathrm{l}$ (July) to $3.2 \mathrm{mg} / \mathrm{l}$ (October)

The result of ANOVA showed variations in oxygen concentration between stations and between was found to be significant at $0.05 \%$ level (Table 4).

\section{Discussion}

The higher rainfall recorded during monsoon months (October to December) and lower values during summer months (April to June). The present trend observed was in agreement with the observations made by earlier workers [21-24].
Variation in atmospheric temperature can influence the physicochemical characteristics of coastal and estuarine waters to a great extend. The higher values of atmospheric temperature in summer and lower values in monsoon observed in the present study confirmed the established trends along the southeast coast and is in agreement with the observations made by Rajasekar [21], Saravanan [22], Rajaram [23], Sundaramanickam [24], Ganesan [25], Sampath Kumar [26].

The surface water temperature largely depends upon the intensity of solar radiation, evaporation, freshwater influx, cooling and mixing due to currents and tidal flow. Surface water temperature also showed a similar trend of monthly variation as that of air temperature and the high values were reported during the summer and lower values during the monsoon season. The gradual increase in water temperature from monsoon to summer is directly related to atmospheric conduction and radiation. Similar findings were reported by Rajasekar [21], Saravanan [22], Rajaram [23], Sundaramanickam [24], Ganesan [25].

Salinity is considered to be the basic and prime factor among the environmental variables in the marine environment which influences greatly the dynamic situation of the estuarine and coastal waters by the inflow of freshwater and the prevailing temperature. It is one of the most fluctuating parameters, typified with wide range of variations in both estuarine and coastal environments. Generally, the changes in the salinity in the brackish water habitats such as estuary, backwater, mangroves and coastal waters are due to the influx of freshwater from river, by land runoff caused by monsoon, or by tidal variations. The maximum salinity was recorded during the summer and the minimum during monsoon months during the study period. Higher values in summer could be attributed to high degree of evaporation with decreased freshwater inflow and land drainage. Drop in salinity during monsoon is related to heavy showers and consecutive floodwater from

\begin{tabular}{|l|c|c|c|c|c|}
\hline Source of Variation & SS & df & MS & F & F crit \\
\hline Rows & 1140.513 & 23 & 49.58754 & 23.47393 & $4.01 \mathrm{E}-24$ \\
\hline Columns & 48.04583 & 3 & 16.01528 & 7.58137 \\
\hline Error & 145.7592 & 69 & 2.112452 & & 0.000187 \\
\hline Total & 1334.318 & 95 & & & \\
\hline
\end{tabular}

Table 1: Two-way ANOVA for differences in surface water temperature between seasons along Muthupettai coastal waters during the study period (January-2010 to December-2011).

\begin{tabular}{|l|c|c|c|c|c|}
\hline Source of Variation & SS & df & MS & F & P-value \\
\hline Rows & 2620.99 & 23 & 113.9561 & 13.76525 & $1.29 \mathrm{E}-17$ \\
\hline Columns & 10.03125 & 3 & 3.34375 & 0.403906 & 0.750645 \\
\hline Error & 571.2187 & 69 & 8.278533 & \\
\hline Total & 3202.24 & 95 & & \\
\hline
\end{tabular}

Table 2: Two-way ANOVA for differences in Salinity between seasons along Muthupettai coastal waters during the study period (January-2010 to December-2011).

\begin{tabular}{|l|c|c|c|c|c|}
\hline Source of Variation & SS & df & MS & F & F crit \\
\hline Rows & 9.536562 & 23 & 0.414633 & 11.88923 & $5.83 \mathrm{E}-16$ \\
\hline Columns & 0.006146 & 3 & 0.002049 & 0.058742 & 0.981173 \\
\hline Error & 2.406354 & 69 & 0.034875 & \\
\hline Total & 11.94906 & 95 & & \\
\hline
\end{tabular}

Table 3: Two-way ANOVA for differences in pH between seasons and stations along Muthupettai coastal waters during the study period (January-2010 to December-2011).

\begin{tabular}{|l|c|c|c|c|c|}
\hline Source of Variation & SS & df & MS & F & P-value \\
\hline Rows & 13.88135 & 23 & 0.603537 & 2.988639 & 0.00024 \\
\hline Columns & 14.73547 & 3 & 4.911822 & 24.32272 & $7.53 \mathrm{E}-11$ \\
\hline Error & 13.93412 & 69 & 0.201944 & \\
\hline Total & 42.55094 & 95 & & 2.737492 \\
\hline
\end{tabular}

Table 4: Two-way ANOVA for differences in DO between seasons and stations along Muthupettai coastal waters during the study period (January-2010 to December-2011) 


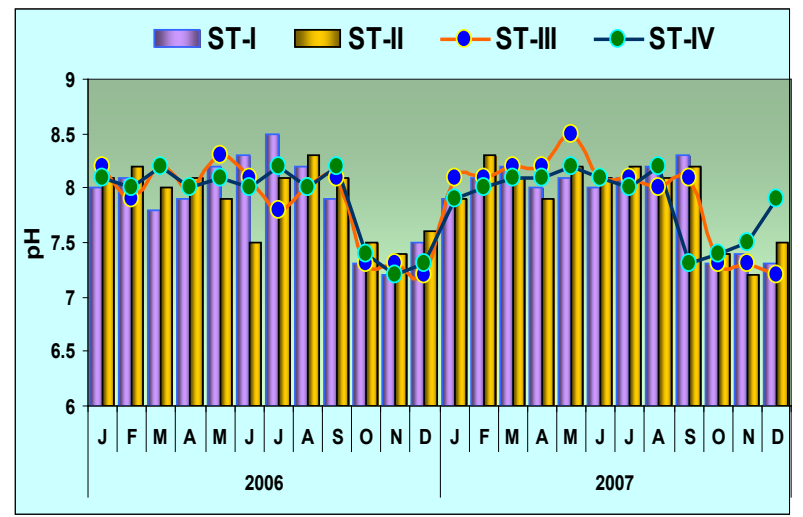

Figure 5: Hydrogen-ion concentration $(\mathrm{pH})$ recorded in the Muthupettai waters during January-2010 to December-2011.

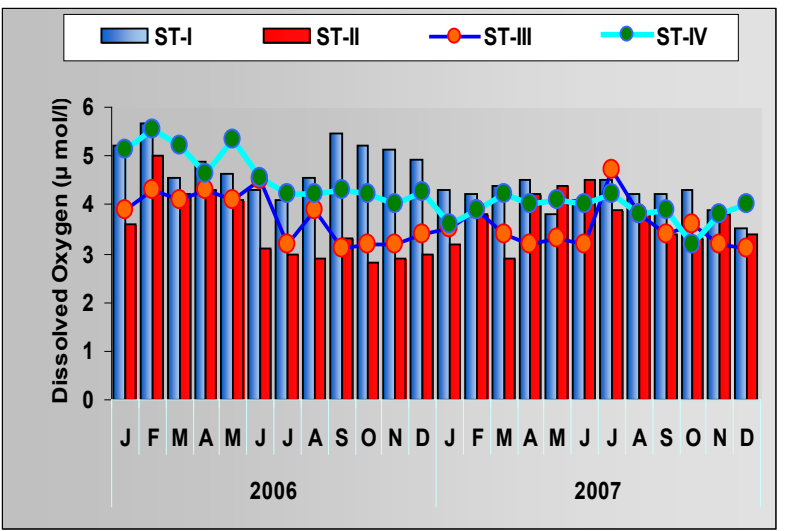

Figure 6: Illustrated the Dissolved Oxygen (DO) recorded along Muthupettai waters at station I to IV during the study period (January-2010 to December-2011).

up streams as reported by Rajaram [23], Sundaramanickam [24], and Mistra et al. [27].

The hydrogen-ion concentration $(\mathrm{pH})$ often changes with time due to temperature-salinity changes and biological activity. The $\mathrm{pH}$ remained alkaline throughout the study period in all the stations with maximum values during the summer, which could be attributed to the high salinity of water and also due to the uptake of carbondioxide by the photosynthetic organisms. The photosynthetic activity may cause high $\mathrm{pH}$, because of bicarbonate degradation by carbonic anhydrase associated with photosynthesis [28]. Most of the natural waters are generally alkaline due to the presence of sufficient quantities of carbonate [29]. Generally higher values of $\mathrm{pH}$ were recorded at stations I and II than at station III and VI. Trivedy and Goel [29] have opined that the $\mathrm{pH}$ of water changes with time due to exposure to biological activity and temperature. The low values of $\mathrm{pH}$ noticed during monsoon season may perhaps be due to dilution and mixing of coastal waters by rain floods that leads to reduction in salinity and temperature and decomposition of organic matter. The present findings are in agreement with that of Hydrobiological studies in the gradient zone of the Vellar estuary $[26,27,30,31]$.

Dissolved oxygen is one of the most important parameters, which reflects the physical and biological processes of water. The dissolved oxygen content depends upon the photosynthetic activities, monsoonal floods and the turbulence caused by winds [32]. The dissolved oxygen concentration depends directly on the monsoonal dissolved oxygen and also on the nature and abundance of the planktonic organisms; salinity etc. In the present study, the dissolved oxygen concentration was low during summer and high during monsoon months in all the stations of Muthupettai waters. Hung [33] opined that temperature is a major factor controlling oxygen saturation in water. Solubility of oxygen in water is inversely proportional to temperature [34]. The low dissolved oxygen concentration observed during summer may be attributed to the higher salinity of the water, higher temperature and less inflow of freshwater coupled with biological processes such as consumption of available oxygen by the organisms for respiration and active decomposition of organic matter during summer month [35]. During 2010, the dissolved oxygen concentration was higher compared to 2011 , which may perhaps be due to higher rainfall recorded during that period. The trend noticed in the present study is in accordance with the findings of hydrology and heavy metals [23-27, 30].

There is an increasing interest in the recent years to enhance the fishery productivity of a scientific basis. The growth, morphological development and ontogeny of fish eggs and larvae of commercially important fish species have to be studied well to enhance the productivity through the aquaculture practices. Special attention is being paid to biochemical, physiological, biotechnological and hormonal manipulation of gonadal development, sex determination, sex reversal and production of fertilisable gametes as well as to development, growth and brood stock management in relation to eggs and larval quality. Finfish eggs are needed in the aquatic life as they play basic role in the biodiversity of larvae and adult fishes. The landing of fishes which is increase or decrease is depending on the environmental conditions. However, the sampling sites were observed that, manmade and anthropogenic activities can affect the quality of water. There was determining the decrease a living capacity of adult fish and exclude egg and larval fish survival.

\section{References}

1. Blaxter JHS, Hunter JR (1982) The biology of clupeoid fishes. Adv Mar Biol 20: 1-223.

2. Leggett WC, Deblois E (1994) Recruitment in marine fishes: Is it regulated by starvation and predation in the egg and larval stages. Neth J Sea Res 32:119134

3. Loneragan NR, Bunn SE (1999) River flows and estuarine ecosystems: Implications for coastal fisheries from a review and a case study of the Logan River, southeast Queensland. Aust J Ecol 24: 431-440.

4. Stratoudakis Y, Bernal M, Borchers D, Borges M, Cardador F (2003) Changes in the distribution of sardine eggs and larvae off Portugal, 1985-2000. Fish Oceanograp 12: 49-60.

5. Ishikawa S, Suzuki K, Inagaki T, Watanabe S, Kimura Y, et al. (2001) Spawning time and place of the Japanese eel Anguilla japonica in the North Equatorial Current of the western North Pacific Ocean. Fish Sci 67: 1097-1103.

6. Borja A, Uriarte A, Egana J, Motos L, Valencia V (1998) Relationships between anchovy (Engraulis encrasicolus) recruitment and environment in the Bay of Biscay (1967e1996). Fisheries Oceanography 7: 375-380.

7. Borja A, Uriarte A, Egana J (2002) Environmental factors and recruitment of mackerel, Scomber scombrus L. 1758, along the north-east Atlantic coasts of Europe. Fish Oceanograp 11: 116-127.

8. Moyle PB, Cech JJ (1996) Fishes: an introduction to ichthyology. Prentice Hall, New Jersey.

9. Nambudripad KD, James EJ (1987) Instrumentation and methods of observation for studies in estuarine dynamics with special reference to Malabar Coast Trivandrum. Proc Natl Sem Estuar Management 49-51.

10. Ramamirtham CP, Jayaraman R (1963) Some aspects of the hydrographical conditions of the backwaters around Wellingdon Island (Cochin). J Mar Biol Ass India 5: 170-177. 
Citation: Selvam J, Varadharajan D, Babu D, Balasubramanian T (2013) Impact of Physico-Chemical Parameters on Finfish Eggs Diversity from Muthupettai, South East Coast of India. J Environ Anal Toxicol 3: 185. doi:10.4172/2161-0525.1000185

11. Qasim SZ, Bhattathiri PMA, Abidi SAH (1968) Solar radiation and its penetration in a tropical estuary. J Exp Mar Biol Ecol 2: 87-103

12. Nair KKC, Tranter DJ (1971) Zooplankton distribution along salinity gradient in the Cochin backwater before and after the monsoon. J Mar Biol Ass India 13: 203-210.

13. Zingde MD, Sharma P, Sabnis MM (1985) Physico - chemical investigation in Auranga river estuary (Gujarat). Mahasagar Bull Natl Inst Oceanogr 18: 307 321.

14. Padmavathi G, Goswami SC (1996) Zooplankton ecology in the Mandovi Zuarie estuarine system of Goa, West coast of India. Indian J Mar Sci 25: 268273

15. Thangaraja $M(1984)$ Laboratory reared fish eggs and larvae and subsequent stages from plankton of Vellar estuary, Porto Novo. II. The flat fish, Cynoglossus puncticeps. Mahasagar Bull Natl Inst Oceanog 17: 103-111.

16. Prabha Devi L (1986) Environmental inventory of tidal and gradient zone of Coleroon estuary, southeast coast of India. Ph.D thesis, Annamalai University, India 241.

17. Ranga Rao U, Ramana YV, Reddy BSR (1988) Salinity and current distribution in the Godawari estuary, east coast of India. Indian J Mar Sci 17: 14-18.

18. Satpathy KK (1996) Seasonal distribution of nutrients in the coastal waters of Kalpakkam, east coast of India. Indian J Mar Sci 25: 221-224

19. Qasim SZ (1973) An appraisal of the studies on maturation and spawning in marine teleosts from the Indian waters. Indian J Fish 20: 166-181.

20. Strickland JDH, Parsons TR (1972) A practical handbook of seawater analysis. Bull Fish Res Bd Canada 167: 310-322.

21. Rajasekar M (1998) Environmental inventory on Vellar estuary (Southeas coast of India) in relation to shrimp forming. Ph.D. thesis, Annamalai University, India.

22. Saravanan S (1999) Studies on the estuarine hermit crab, Diogenes avarus Hellar (Crustacea: Decemberapoda: Anomura). Ph.D. thesis, Annamalai University, India.

23. Rajaram R (2001) Studies on hydrobiology and mercury content in Uppanar estuary (Cuddalore, Southeast coast of India). Ph.D. thesis, Annamalai University, India.

24. Sundaramanickam A (2004) Distribution of finfish larvae in relation to hydrographical parameters in parangipettai coast and adjacent water (South East Cost of India). Ph.D. Thesis, Annamalai University, India.

25. Ganesan I (1992) Ecobiology of seaweeds of the Gulf of Mannar with specia reference to hydrography and heavy metals. Ph.D. thesis, Annamalai University 162.

26. Sampath Kumar $P$ (1992) Investigation on plankton in relation to hydrology and heavy metals in the Tranquebar - Nagapattinam coast, India. Ph.D. thesis, Annamalai University, India.

27. Mistra A, Patra KC, Panigraphy RC (1990) Seasonal variations of some hydrographical parameters in tidal creek opening into the Bay of Bengal. Mahasagar Bull Natl Inst Oceanogr 23: 55-62.

28. Ruttner F (1953) Fundamentals of limnology. University of Toronto Press.

29. Trivedy RK, Goel PK (1984) Physicochemical analysis of water. In: Chemical and Biological Methods for Water Pollution Studies. Kerala, India. Environ Publ 35-95.

30. Chandaran R (1982) Hydrobiological studies in the gradient zone of the Vellar estuary. Ph.D. thesis, Annamalai University, India 198.

31. Chandran R, Ramamoorthi K (1984) Hydrobiological studies in the gradient zone of the Vellar estuary. 1: Physicochemical parameters. Mahasagar Bull Natl Inst Oceanogr 17: 69-77.

32. Jegathesan G (1974) Studies on the particulate matter of Vellar estuary and near shore waters of Porto-Novembero. Ph. D. thesis, Annamalai University 185

33. Hung TC (1972) Investigations of chemicals nutrients in South China Sea. Bull Fust Chem Acad Sinica 20: 77-89.

34. Carpenter JH (1996) New measurements of oxygen solubility in pure and natural water. Limnol Oceanogr 11: 264-277.

35. Qasim SZ, Wellershaus S, Bhattathiri PMA, Abidi SAH (1969) Organic production in a tropical estuary. Proc Indian Acad Sci 69: 51-94. 